\title{
Profit Distribution Management Determinant (Empirical Study in Indonesian Sharia Banks)
}

\author{
${ }^{1 *}$ Ardiani Ika Sulistyawati, ${ }^{2}$ Aristi Aprilia Asmaraputri, ${ }^{3}$ Aprih Santoso \\ ${ }^{1,2,3}$ Fakultas Ekonomi Universitas Semarang (USM), Indonesia \\ *Email korenpondensi: aprihsantoso@usm.ac.id
}

\begin{abstract}
The purpose of this research is to know the factors affecting to profit distribution management of Sharia Banks in Indonesia on the period 2013 until 2016. Variabel dependent of this research is profit distribution management. While the independen of this research is capital adequancy, effectiviness of third party funds, financial risk, gross domestic of product growth, propotion of investment financial, proportion of third party funds, loss of earning assets, age of bank, BOPO, Bi-rate.This research use sharia banks which registered in Bank Indonesia on 2013 until 2016 period. Collecting data of this research use purposive sampling method. The test data analysis use classic assumption test, hypothesis test, and data analysis of multiple regression.The result of the hypothesis test is that capital adequancy, effectiveness of third party funds, financial risk, loss of earning assets, BOPO and Bi rate have no effect to profit distribution management. While gross domestic of product growth, proportion of investment, proportion of third party funds and age of bank have the effect of profit distriburion management. The implication is that Islamic banking must also require good performance supervision according to banking regulators.
\end{abstract}

Keywords: Profit, Financial, Risk, Investment

Saran sitasi: Sulistyawati, A. I., Asmaraputri, A. A., \& Santoso, A. (2019). Profit Distribution Management Determinant (Empirical Study in Indonesian Sharia Banks). Jurnal Ilmiah Ekonomi Islam, 5(03), 245-264. doi: http://dx.doi.org/10.29040/jiei.v5i3.701

DOI: $\underline{\text { http://dx.doi.org/10.29040/jiei.v5i3.701 }}$

\section{Pendahuluan}

Bank syariah adalah bank yang didasarkan pada prinsip syariah yang mengedepankan prinsip muamalah, keadilan, dan kebersamaan dalam berusaha, baik dalam memperoleh keuntungan maupun dalam menghadapi risiko. UU No. 21 tahun 2008 telah menjelaskan bahwa perbankan syariah melakukan kegiatan usahanya berlandaskan pada nilai-nilai keadilan, kemanfaatan, keseimbangan, dan keuniversalan (rahmatan lil 'alamin ) serta didasarkan pada prinsip syariah, demokrasi ekonomi, dan prinsip kehatihatian. Perbankan syariah di Indonesia berkembang sangat cepat dan telah eksis dalam perekonomian nasional.

Dalam proses penghimpunan dana maupun penyaluran dana, bank syariah menerapkan sistem bagi hasil. Bagi hasil yang dimaksud adalah bentuk return (perolehan kembalinya) dari kontrak investasi, dari waktu ke waktu, tidak pasti dantidak tetap (Karim, 2004). Besar kecilnya perolehan kembali itu tergantung pada hasil usaha yang benar-benar terjadi. Jika usaha mendapatkan keuntungan, porsi bagi hasil adalah sesuai kesepakatan. Namun jika terjadi kerugian maka porsi bagi hasil disesuaikan dengan 
kontribusi masing-masing pihak. Dapat disimpulkan bahwa bagi hasil adalah suatu sistem yang meliputi tata cara pembagian hasil usaha antara penyedia dana (shahibul mall) dengan pengelola dana (mudharib) (Muhammad, 2005).

Keuntungan bagi hasil dapat diperoleh jika dana nasabah di bank syari'ah diinvestasikan terlebih dahulu ke dalam bentuk usaha. Berbeda dengan simpanan nasabah di bank konvensional, disalurkan atau tidaknya simpanan tersebut, bank tetap membayar bunganya. Menurut Bank Indonesia, kewajiban bank syari'ah dalam membagi keuntungan yang didapat dengan memanfaatkan dana nasabah melalui pembiayaan berdasarkan nisbah yang disekapati setiap periodenya disebut Distribusi Bagi Hasil. Mulyo dan Mutmainah (2013) menjelaskan profit distribution adalah pembagian keuntungan bank syariah kepada deposan berdasarkan nisbah yang disepakati setiap bulannya. Profit distribution diatur berdasarkan produk yang menjadi pilihan deposan terhadap bank, serta persetujuan nisbahnya. Pihak manajemen syariah harus memperhatikan betul tingkat profit distribution melalui pengelolaannya (profit distibution management). Profit Distribution Management dapat diartikan sebagai aktivitas yang dilakukan manajer dalam mengelola pendistribusian laba untuk memenuhi kewajiban bagi hasil bank syariah kepada deposannya. Di Indonesia, manajer bank syariah melakukan profit distribution management (PDM) yang mengacu pada suku bunga bank konvensional. Hal ini terkait dengan tipe deposan di Indonesia. Karim dan Afif (2006) dalam Mulyo dan Mutmainah(2013) menyatakan bahwa di Indonesia ditemukan tiga segmentasi pasar, yaitu sharia loyalist, floating segment dan convetional loyalist. Di Indonesia, penelitian Khairunnisa (2002) (dalam Mulyo dan Mutmainah, 2013) menemukan bahwa nasabah mengincar profit maximization. Survey dari Karim (2003) dalam Mulyo dan Mutmainah (2013) juga menyebutkan bahwa $70 \%$ nasabah perbankan syariah adalah nasabah yang berada pada floating segment, yang sensitif pada tingkat keuntungan. Muhlis (2011) dalam Mulyo dan Mutmainah (2013) bahwa perilaku menabung di bank syariah paling dipengaruhi oleh tingkat bagi hasil (profit distribution).

Penelitian Farook,et. al (2009) tentang profit distribution management (PDM) mengacu pada suku bunga di beberapa negara. Dalam penelitian yang dilakukan oleh Mulyo dan Mutmainah (2013) meneliti tentang profit disribution management (PDM) yang mengacu pada suku bunga di perbankan syariah di Indonesia. Mulyo dan Mutmainah (2013) menggunakan profit distribution management sebagai variabel dependen, kemudian faktor eksternal dan internal bank sebagai variabel independen.

Berbeda dengan penelitian yang dilakukan oleh Mulyo dan Mutmainah (2013),penelitian ini menggunakan laporan keuangan triwulanan dari periode triwulan I 2013 hingga periode triwulan ke IV tahun 2016. Penelitian ini pun menggunakan seluruh variabel independen dari penelitian Mulyo dan Mutmainah (2013) selain itu sesuai dengan saran penelitianMulyo dan Mutmainah (2013) untuk menambahkan variabel yang berasal dari internal dan eksternal bank. Penelitian iniakan menggunakan variabel rasio keuangan yang dinilai berpengaruh terhadap profit distribution dari penelitian-penelitian terdahulu yaitu Farook et al, (2009), Andraeny (2011), Kartika dan Adityawarman (2012), Wibowo dan Syaichu (2013), Wafaretta et al, (2015) , dalam penelitian ini akan digunakan variabel internal perusahaan yaitu BOPO (Biaya Operasional Pendapatan Operasional) serta variabel eksternal perusahaan yaitu $\mathrm{Bi}$ rate. Adapun tujuan penelitian adalah : (1) menguji secara empris pengaruh Kecukupan Modal (KM); Efektivitas Dana Pihak Ketiga (EDPK); Risiko Pembayaran (RP); Pertumbuhan Produk Domestik Bruto (PPDB); Proporsi Pembiayaan Non Investasi (PPNI); Proporsi Dana Pihak Ketiga (PDPK); Penyisihan Penghapusan Aktiva Produktif (PPAP); Umur Bank (UB); dan Biaya Operasional Pendapatan Operasional (BOPO) serta BI Rate terhadap Profit Distribution Management (PDM) bank umum syariah di Indonesia. 


\section{Kajian Pustaka}

\subsection{Profit Distribution Management}

Profit Distribution Management merupakan variabel dependen dalam penelitian ini. Berdasarkan model penelitian Farook et al. (2009)dalam Mulyo dan Mutmainah (2013). Penggunaan asset spread sebagai metode untuk menghitung PDM yang mengacu pada suku bunga. Asset spread adalah absolutespread antara Return On Asset (ROA) dan average Return On Invesment Account Holder (ROIAH) yang merupakan rata- rata return bagi hasil deposan. Asset spread dapat dirumuskan sebagai berikut :

Asset spread $=\mid($ ROA - average ROIAH $) \mid$

Untuk rata-rata ROIAH dapat dihitung dengan menggunakan "total pendapatan yang harus dibagi" dibagi dengan "saldo rata-rata instrumen bagi hasil deposan". Kedua item tersebut dapat dilihat pada Laporan Distribusi Bagi hasil dengan rumus sebagai berikut :

average $\mathrm{ROIAH}=$ pendapatan yang harus dibagi saldo rata-rata instrumen bagi hasil deposan

Asset spread merupakan indikator paling kuat untuk menghitung Profit Distribution Management. Semakin tinggi asset spread mengindikasi adanya pendistribusian laba kepada deposan yang jauh dari asset return. Hak tersebut memperkuat adanya tindakan Profit Distribution Management yang mengacu pada suku bunga sesuai dengan penelitian Sundararajan (2005) dan Farook et al (2009) dalam Mulyo dan Mutmainah (2013).

\subsection{Kecukupan Modal (CAR)}

Kecakupan Modal diukur dengan rasio (CAR) Capital Adequacy Ratio. Rasio CAR pada bank syariah dihitung dengan perbandingan antara modal sendiri terdiri dari modal inti dan modal pelengkap (maksimal $100 \%$ dari modal inti) dibanding dengan aset tertimbang menurut resiko (Muhammad, 2009 dalam Mulyo dan Mutmainah (2013). CAR diperoleh dari modal bank dibagi total Aset Tertimbang Menurut Resiko (ATMR), sehingga dirumuskan dengan rumus berikut :

Capital Adequacy Ratio CAR $=\frac{\text { Modal Bank }}{\text { Total ATMR }} \chi 100 \%$

\subsection{Efektifitas Dana Pihak Ketiga (EDPK)}

Efektivitas Dana Pihak Ketiga (EDPK) dapat diukur dengan rasio (FDR) Financing to Deposit Ratio. FDR diukur dengan menggunakan skala pengukuran rasio yang ada pada laporan keungan bank syariah. FDR dirumuskan dengan rumus berikut (Mawardi, 2005 dalam Mulyo dan Mutmainah, 2013) :

Financing to Deposit Ratio $=\frac{\text { Total Pembiayaan }}{\text { Total Dana Pihak Ketiga }} \times 100 \%$

\subsection{Resiko Pembiayaan (RP)}

Resiko Pembiayaan (RP) dapat diukur dengan rasio (NPF) Non Perfoming Financing. NPF merupakan rasio untuk mengukur kemampuan bank dalam menjaga resiko kegagalan pengembalian pembiayaan oleh debitur. NPF dirumuskan dengan rumus berikut (Mawardi 2005 dalam Mulyo dan Mutmainah, 2013) :

Net Performing Financing $=\frac{\text { Total Pembiayaan Bermasalah }}{\text { Total Pembiayaan }} \chi 100 \%$

\subsection{Resiko Pembiayaan (RP)}

Resiko Pembiayaan (RP) dapat diukur dengan rasio (NPF) Non Perfoming Financing. NPF merupakan rasio untuk mengukur kemampuan bank dalam menjaga resiko kegagalan pengembalian pembiayaan oleh debitur. NPF dirumuskan dengan rumus berikut (Mawardi 2005 dalam Mulyo dan Mutmainah, 2013) :

Net Performing Financing $=\frac{\text { Total Pembiayaan Bermasalah }}{\text { Total Pembiayaan }} x_{100 \%}$

\subsection{Pertumbuhan Produk Domestik Bruto (PPDB)}

Produk Domestik Bruto (PDB) digunakan sebagai alat ukur utama tingkat kesejahteraan ekonomi suatu negara. PDB mampu mengukur kemampuan dari suatu negara untuk memperbesar outputnya dalam laju yang lebih cepat daripada tingkat pertumbuhan penduduknya (Nasutin, 2009dalam Mulyo dan Mutmainah, 2013). PPDB dirumuskan sebagai berikut (Farook et al, 2009 dalam Mulyo dan Mutmainah 2013) :

$\mathrm{PPDB}=\frac{\mathrm{PDBt}-\mathrm{PDBt}-1}{\mathrm{PDBt}-1}$ 


\subsection{Proporsi Pembiayaan Non Investasi} (PPNI)

Proporsi Pembiayaan Non Investasi (PPNI) dapat diukur dengan rasio (LATA) Loan Asset to Total Asset. LATA dapat dihitung dengan prosentase loan asset sebagai proporsi dari total asset. LATA dirumuskan dalam rumus berikut (Farook et al. 2009 dalam Mulyo dan Mutmainah, 2013):

$$
\text { Loan Asset to Total Asset LATA }=\frac{\text { Loan Asset }}{\text { Total Asset }}
$$

\subsection{Dana Pihak Ketiga (PDPK)}

Proporsi Dana Pihak Ketiga (PDPK) merupakan variabel yang menggambarkan seberapa proporsi dana pihak ketiga bank. PDPK dirumuskan dalam rumus sebagai berikut (Farook et al. 2009 dalam Mulyo dan Mutmainah, 2013):

$$
\text { PDPK }=\frac{\text { Dana Pihak Ketiga }}{\text { Total Aset }}
$$

\subsection{Penyisihan Penghapusan Aktiva \\ Produktif (PPAP)}

PPAP adalah penyisihan yang harus dibentuk, baik dalam rupiah maupun valuta asing untuk menutup kemungkinan kerugian yang timbul sehubungan dengan penanaman dana ke dalam aktiva produktif (Surat Keputusan Direksi Bank Indonesia No. 31/148/DIR/2008). Bank Indonesia melalui PBI No. 5/9/2003 tentang Penyisihan Penghapusan Aktiva Produktif (PPAP) mewajibkan bank syariah membuat PPAP. PPAP dibentuk sebesar (1) 5\% dari aset produktif yang digolongkan dalam perhatian khusus, (2) $15 \%$ dari asset produktif yang digolongkan kurang lancar setelah dikurangi nilai agunan, (3) $50 \%$ dari aset produktif yang digolongkan diragukan setelah dikurangi nilai agunan dan (4) 100\% dari aset produktif yang digolongkan macet setelah dikurangi nilai agunan.

\subsection{Umur Bank (UB)}

Pengalaman dalam menjalankan usaha bagi bank akan mempengaruhi keberadaan bank dalam menghadapi persaingan. Farook et al (2009 dalam Mulyadi dan Mutmainah, 2013) menyatakan cara mengukur variabel ini adalah dengan menghitung selisih dari bulan berdirinya bank hingga akhir periode penelitian. Karena penelitihan ini menggunakan Laporan Tahunan dalam data penelitiannya, maka untuk mencari umur bank menggunakan rumus sebagai berikut : Umur Bank = Bulan dakam Periode Penelitian - Bulan berdirinya Bank

\subsection{Biaya Operasional Pendapatan Operasional (BOPO)}

Rasio biaya adalah rasio yang menunjukkan tingkat efisiensi kinerja operasional suatu bank. Pendapatan bank yang tinggi, maka tinggi juga pendapatan yang akan diperoleh nasabah, begitu juga sebaliknya (Muhammad 2005). BOPO digunakan untuk mengukur kemampuan bank dalam mengendalikan biaya operasional terhadap pendapatan operasional. Menurut Bank Indonesia, BOPO dapat dirumuskan sebagai berikut:

$$
\text { BOPO }=\frac{\text { Biaya Operasional }}{\text { Pendapatan Operasional }} \times 100 \%
$$

\subsection{BI Rate}

Menurut Bank Indonesia, BI rate adalah suku bunga kebijakan yang mencerminkan sikap atau stance kebijakan moneter yang ditetapkan oleh bank Indonesia dan diumumkan kepada publik. Dengan mempertimbangkan pula faktorfaktor lain dalam perekonomian, Bank Indonesia pada umumnya akan menaikkan rate apabila inflasi ke depan diperkirakan melampaui sasaran yang telah ditetapkan, sebaliknya Bank Indonesia akan menurunkan BI rate apabila inflasi ke depan diperkirakan di bawah sasaran yang telah ditetapkan.Tingkat suku bunga yaitu sebagai harga dari penggunaan uang untuk jangka waktu tertentu yang disesuaikan dengan tingkat permintaan dalam pasar investasi sebagai imbalan atas penanaman dana pihak ketiga (Sunaryo, 2014).

\section{Pengaruh Kecukupan Modal Terhadap Profit Distibution Management}

Kecukupan modal menggambarkan kemampuan bank dalam mempertahankan modal yang mencukupi untuk menutup risiko kerugian yang mungkin timbul dari penanaman dana 
dalam aset produktif yang mengandung risiko, serta untuk pembiayaan dalam aset tetap dan investasi. Capital Adequacy Ratio (CAR) dapat digunakan untuk mengukur kecukupan modal pada bank syariah (Muhammad, 2005).

Semakin besar rasio ini, maka kesehatan bank dikatakan membaik. Hal ini dikarenakan besar modal yang dimiliki bank mampu menutupi risiko kerugian yang timbul dari penanaman dana dalam aset produktif yang mengandung risiko, serta dapat digunakan untuk pembiayaan penanaman dalam aset tetap dan investasi. Berdasarkan ketentuan Bank of International Settlement, bank yang dinyatakan sebagaibank sehat harus memiliki CAR paling sedikit $8 \%$ (Muhammad, 2005 dalam Mulyo dan Mutmainah, 2013).

$\mathrm{H}_{1}$ : Kecukupan modal berpengaruh terhadap Profit Distribution Management

\section{Pengaruh Efektivitas Dana Pihak Ketiga Terhadap Profit Distibution Management}

Efektivitas dana pihak ketiga (EDPK) merupakan cerminan dari fungsi intermediasi bank, yaitu dalam menyalurkan dana pihak ketiga ke pembiayaan. Efektivitas dana pihak ketiga dapat diukur dengan Financing to Deposit Ratio (FDR). Semakin tinggi rasio ini (menurut Bank Indonesia 85\%-100\%), semakin baik tingkat kesehatan bank, karena pembiayaan yang disalurkan bank lancar, sehingga pendapatan bank semakin meningkat. Mempertahankan likuiditas yang tinggi akan mempearlancar customer relationship tetapi tingkat bagi hasil akan menurun karena banyaknya dana yang menganggur. Di lain pihak likuiditas yang rendah menggambarkan kurang baiknya posisi likuiditas suatu bank. Karena itu apabila efektivitas dana pihak ketiga yang diukur dengan rasio FDR semakin tinggi, maka bagi hasil akan semakin tinggi juga. Hal tersebut bila dikaitkan dengan teori stakeholder, maka bank syariah akan mengurangi tingkat PDM yang mengacu pada suku bunga. Berkurang tingkat PDM dikarenakan bank telah mampu memanage deposannya dengan tingkat profit distribution yang sudah tinggi.

$\mathrm{H}_{2}$ : Efektivitas dana pihak ketiga berpengaruh terhadap Profit Distribution Management

\section{Pengaruh Resiko Pembiayaan Terhadap Profit Distibution Management}

Risiko pembiayaan (RP) digunakan untuk mengukur tingkat permasalahan pembiayaan yang dihadapi oleh bank syariah. Resiko pembiayaan dapat diukur dengan Non Performing Financing (NPF). Net performing financing merupakan rasio untuk mengukur kemampuan bank dalam menjaga risiko kegagalan pengembalian kredit oleh debitur. Semakin tinggi rasio ini, menunjukkan kualitas pembiayaan bank syariah yang semakin buruk. Bank Indonesia melalui Surat Edaran Bank Indonesia No.6/23/DPNP tanggal 31 Mei 2004 menetapkan kriteria rasio NPL yang ideal di bawah $6 \%$. Semakin baik kualitas pembiayaan yang disalurkan bank, makin kecil tingkatnet performing finance.

Apabila resiko pembiayaan semakin besar, maka bagi hasil semakin rendah. Bila dikaitkan dengan teori stakeholder, maka bank syariah akan menaikkan tingkat profit distribution management yang mengacu pada suku bunga untuk memuaskan/memanage deposannya. Bertambahnya tingkat profit distribution management dikarenakan tingkat profit distribution yang diperoleh deposan sudah rendah. $\mathrm{H}_{3}$ : Resiko pembiayaan berpengaruh terhadap Profit Distribution Management.

\section{Pengaruh Pertumbuhan Produk Domestik Bruto Terhadap Profit Distibution Management}

Produk domestik bruto merupakan alat ukur utama tingkat kesejahteraan ekonomi suatu negara yang dicerminkan dengan adanya kenaikan antara produk domestik bruto mendatang dengan produk domestik bruto periode sebelumnya. Kondisi perekonomian yang baik menandakan kegiatan produksi dalam negeri sehat dan dicerminkan oleh pertumbuhan produk 
domestik bruto di setiap waktu. Ketika terjadi hal yang sebaliknya yaitu perekonomian negara yang buruk seperti resesi, maka akan terjadi peningkatan tingkat penggangguran dan penurunan pertumbuhan bisnis. Dalam resesi terdapat kemungkinan bahwa individu maupun pebisnis akan kesuliatan atau bahkan tidak mampu memenuhi kewajiban membayar hutang kepada bank (Farook, et al, 2009). Akibatnya, aset yang didanai oleh deposan (Investment Account Holder/IAH) akan memiliki kinerja yang memburuk. Bila dikaitkan dengan teori stakeholder dimana bank harus memanage deposannya, maka bank syariah akan mengorbankan laba mereka sendiri atau bahkan modal pemegang saham untuk mempertahankan competitive return kepada IAH. Saat-saat itulah bank syariah akan melakukan profit dstribution management yang mengacu pada suku bunga (Farook et al, 2009).

$\mathrm{H}_{4}$ : Pertumbuhan produk domestik bruto berpengaruh terhadap ProfitDistribution Management.

\section{Pengaruh Proporsi Pembiayaan Non Investasi Terhadap Profit Distibution Management}

Proporsi pembiayaan Non Investasi (PPNI) bank syariah mengacu pada pembiayaan dengan tingkat tetap (sisi piutang). Pembiayaan Non Investasi pada bank syariah dilakukan dengan akad Murabahah, Salam, Istishna' dan Ijarah. Biasanya instrumen tersebut berada dalam jangka waktu 3 bulan hingga 8 tahun. Pembiayaan jenis ini menggunakan tingkat harga dan keuntungan yang disepakati di awal kontrak. Selama kontrak ini berjalan dan pembayaran diangsur, waktu semakin berjalan. Saat berjalannya waktu, terdapat kemungkinan terjadi perubahan tingkat suku bunga, sehingga bank syariah berhadapan dengan fund gap antara asset returns yang sudah ditetapkan di awal kontrak dengan dana deposan yang digunakan untuk proses pembiayaan non investasi tersebut.

Deposan sebagai pemilik dana yang tergolong dalam floating segment akan sangat sensitif terhadap perubahan tingkat suku bunga, mereka berharap mendapat return yang tidak kalah menariknya dari bank lain. Kenyatannya dana mereka digunakan oleh bank untuk pembiayaan non investasi yang tergolong menggunakan tingkat harga dan keuntungan yang tetap yang telah disepakati di awal kontrak. Hal ini dinamakan profit rate risk.

Besarnya proporsi pembiayaan non investasi menentukan tingkat dimana bank syariah melakukan profit distribution management untuk return mismatch dalam keadaan pasar dimana terdapat perubahan suku bunga (Farook et al. 2009). Oleh karena itu, semakin tinggi rasio, semakin tinggi tingkat profit distibution management.

H5: Proporsi pembiayaan non investasi berpengaruh terhadap ProfitDistribution Management

\section{Pengaruh Proporsi Dana Pihak Ketiga Terhadap Profit Distibution Management}

Proporsi dana pihak ketiga (PDPK) merupakan variabel yang menggambarkan seberapa besar kebergantungan bank terhadap dana deposan. Dana merupakan masalah utama bagi bank sebagai lembaga keuangan, karena dana yang dihimpun dari masyarakat ternyata merupakan dana terbesar yang paling diandalkan oleh bank. Jika dana tidak cukup, bank tidak mampu melakukan fungsinya dengan maksimal atau bahkan menjadi tidak berfungsi sama sekali. Proporsi dana pihak ketiga merupakan proksi yang menggambarkan seberapa besar ketergantungan bank terhadap dana pihak ketiga.Farook et al. (2009) juga berpendapat bahwa bank syariah dengan proporsi dana pihak ketiga yang lebih kecil daripada dana pemegang saham cenderung tidak mengelola profit distribution management yang mengacu pada suku bunga. Bank syariah tersebut kemungkinan lebih menyediakan profit distribution management yang bersifat konsisten sesuai dengan asset returns yang diperoleh. Hal tersebut bila dikaitkan dengan teori stakeholder dimana bank akan memanage deposannya, maka tingkat 
profit distributon management pun meningkat seiring meningkatnya proporsi dana pihak ketiga.

$\mathrm{H}_{6}$ : Proporsi dana pihak ketiga berpenagruh terhadap Profit Distribution Management

\section{Pengaruh Penyisihan Penghapusan Aktiva Produktif Terhadap Profit Distibution Management}

Bank memiliki suatu kebijakan cadangan, kebijakan tersebut mengacu pada penyisihan kerugian. Bank syariah memiliki kecenderungan untuk membentuk penyisihan kerugian untuk menyerap kerugian di masa depan (Boulila, et al., 2010 dalam Mulyo dan Mutmainah, 2013).

Besarnya penyisihan dalam batasan persentase tertentu ditentukan oleh Bank Indonesia, namun pihak manajemen bank masih diberikan keleluasaan untuk menentukan kualitas aset berdasarkan ketentuan yang diatur dalam PBI tersebut serta membentuk cadangan penyisihan penghapusan aktiva produktif melebihi cadangan yang wajib dibentuk. Oleh karenanya sering kali penyisihan penghapusan aktiva produktif dijadikan objek oleh manajer dalam melakukan manipulasi laga (Tobing dan Anggorowati, 2009 dalam Mulyo dan Mutmainah, 2013).

Konsekuensinya, penyisihan penghapusan aktiva produktif ini mendorong bank untuk lebih berani dalam mengambil risiko dalam melakukan pembiayaan karena tahu bahwa profit distribution ke nasabah terlindungi. Terdapat kemungkinan bahwa bank syariah lebih nyaman melakukan profit distribution management jika terdapat cadangan tersebut (Farook et al, 2009).

$\mathrm{H}_{7}$ : Penyisihan penghapusan aktiva produktif berpengaruh terhadap ProfitDistribution Management

\section{Pengaruh Umur Bank Terhadap Profit Distibution Management}

Menurut Farook,et al. (2009), dalam konteks bank, bank yang baru berdiri sama dengan perusahaan yang baru berdiri. Bank yang baru berdiri tersebut memiliki kekurangan informasi mengenai kondisi bank itu sendiri. Bank yang baru berdiri harus mampu melakukan tindakan yang membangun kepercayaan bagi para stakeholdernya. Farook,et al. (2009) berpendapat bahwa susah bagi perusahaan untuk memulai operasi usahanya terutama mendapatkan laba di awal-awal tahun operasinya. Bagi bank syariah ini merupakan hal yang buruk terutama karena penggunaan sistem bagi hasil. Susahnya mendapatkan laba akan membuat bagi hasil semakin kecil, hal ini akan mengakibatkan deposan menarik dananya dan memindahkannya pada bank yang memberikan return lebih baik (displacement fund).Bila dikaitkan dengan teori stakeholder, maka demi mengurangi resiko ini, bank syariah akan menjaga atau meningkatkan tingkat profit distribution managemen untuk membangun kepercayaan atas deposannya.

$\mathrm{H}_{8}$ : Umur bank berpengaruh terhadap Profit Distribution Management.

\section{Pengaruh Biaya Operasional Pendapatan Operasional Terhadap Profit Distibution Management}

Rasio BOPO merupakan perbandingan antara biaya operasional dan pendapatan operasional. Pengelolaan pembiayaan sangat diperlukan oleh bank, mengingat fungsi pembiayaan sebagai penyumbang pendapatan terbesar bagi bank syariah.

Tingkat kesehatan pembiayaan (NPF) ikut mempengaruhi pencapaian laba bank. Rasio ini juga menjadi salah satu rasio yang dapat digunakan untuk mengukur tingkat kesehatan bank. Untuk menghitung rasio ini dapat melihat laporan labarugiperbankan syariah yang telah diterbitkan. Angka atau nilai maksimal rasio BOPO ini menurut Bank Indonesia yaitu sebesar 90, jika rasio ini melebihi angka 90 ataumelebihi 100 dapat dikatakan bahwa bank tersebut tidak efisien dalam menjalankan kegiatan operaionalnya. Semakin tinggi rasio ini mengartikan bahwa semakin buruk kinerja operasionalbank karena biaya yang dikeluarkan lebih tinggi dibandingkan dengan pendapatan operasional perusahaan. 
Dengan sedikitnya pendapatan yang dihasilkan, akanmemperoleh tingkat bagi hasil yang kecil, sehingga manajer tidak termotivasi untuk melakukan PDM yang tinggi. Jika dikaitkan dengan teori stakeholder, manajer akanmenjaga dana yang ditanam oleh nasabahnya dengan tidak melakukan PDM yang tinggi karena resiko yang timbul tidak dapat diredam dengan adanya sisa dana yangberada di bank.

$\mathrm{H}_{9}$ : Biaya operasional pendapatan operasional berpengaruh terhadap ProfitDistribution Management.

\section{Pengaruh BI rate Terhadap Profit Distibution Management}

BI rate adalah suku bunga kebijakan yang mencerminkan sikap atau stance kebijakan moneter yang ditetapkan oleh bank Indonesia dan diumumkan kepada publik. Sasaran oprasional kebijakan moneter dalam mengimplementasikan BI rate dicerminkan pada perkembangan suku bunga Pasar Uang Antar Bank Over Night (PUAB O/N). Pergerakan di suku bunga PUAB ini diharapkan akan diikuti oleh perkembangan suku bunga deposito, dan pada gilirannya suku bunga kredit perbankan. Bank Indonesia pada umumnya akan menaikkan BI rate apabila inflasi ke depan diperkirakan melampaui sasaran yang telah ditetapkan, sebaliknya Bank Indonesia akan menurunkan $\mathrm{Bi}$ rate apabila inflasi ke depan diperkirakan berada di bawah sasaran yang telah ditetapkan. Hal tersebut bila dikaitkan dengan teori stakeholder, tingginya BI rate mengakibatkan melabatnya pertumbuhan sektor riil dan laju pertumbuhan ekonomi nasional menjadi rendah sehingga tingkat bagi hasil syariah cenderung mengalami penurunan.

$\mathrm{H}_{10}$ : Bi rate berpengaruh terhadap Profit Distribution Management

\section{Metode Penelitian}

Populasi dalam penelitian ini adalah perusahaan perbankan syariah di Indonesia yang terdaftar direktorat Bank Indonesia pada periode triwulan I sampai dengan IV tahun 2013 sampai tahun 2016. Sedangkan kriteria pemilihan sampel menggunakan metode purposive sampling dengan kriteria : (1) Bank Syariah yang tergolong BUS (Bank Umum Syariah), (2) Bank Syariah tersebut menerbitkan laporan keuangan triwulan periode 2013-2016 secara konsisten dan telah dipublikasikan di Bank Indonesia atau pada website masing-masing bank syariah tersebut, dan (3) Bank Syariah memiliki data yang dibutuhkan terkait pengukuran variabel-variabel yang digunakan untuk penelitian selama periode 2013-2016. Jenis data yang digunakan pada penelitian ini adalah data sekunder yang bersifat historis yaitu laporan keuangan triwulan yang diterbitkan bank yang bersangkutan.

Sumber data yang digunakan atau diperoleh dari situs Otoritas Jasa Keuangan dan dari masing-masing bank syariah. Analisis data yang digunakan dalam penelitian ini yaitu analisis statistik deskriptif, pengujian asumsi klasik, pengujian hipotesis, uji koefisien determinasi dan analisis regresi berganda,dengan persamaan:

$Y=a+b_{1} x_{1}+b_{2} x_{2}+b_{3} x_{3}+b_{4} x_{4}+b_{5} x_{5}+b_{6} x_{6}+b_{7} x_{7}+b_{8} x_{8}+b_{9} x_{9}+b_{10} x_{10}+e$ Dimana

Y : Profit Distribution Management (PDM)

a : konstanta

$b_{1}-b_{10}:$ koefisien regresi masing-masing variabel

$x_{1}:$ Kecukupan Modal (KM)

$x_{2}$ : Efektivitas Dana Pihak Ketiga (EDPK)

$x_{3} \quad$ : Resiko Pembiayaan (RP)

$x_{4}$ : Pertumbuhan Produk Domestik Bruto (PPDB)

$x_{5} \quad$ : Proporsi Pembiayaan Non Investasi (PPNI)

$x_{\epsilon} \quad$ : Proporsi Dana Pihak Ketiga (PDPK)

$x_{7}$ : Penyisihan Penghapusan Aktiva Produktif (PPAP)

$x_{\text {a }} \quad:$ Umur Bank (UB)

$x_{9}$ : Biaya Operasional Pendapatan Operasional (BOPO)

$x_{10}: \mathrm{BI}$ Rate

E : variabel gangguan 
Jurnal Ilmiah Ekonomi Islam, 5(03), 2019, 253

\section{Hasil dan Pembahasan}

Berdasarkan kriteria yang sudah ditentukan maka diperoleh jumlah 6 perusahaan bank Syariah dengan jumlah sample 95 laporan keuangan. Adapun kriteria prosedur penelitian di sajikan dalam tablel 1 .

Tabel 1 Daftar Kriteria Sample Penelitian

\begin{tabular}{ll}
\hline \multicolumn{3}{c}{ Kriteria Sample } & Jumlah \\
\hline Bank Umum Syariah yang terdaftar & 11 \\
di Bank Indonesia periode 2013- & \\
2016 & \\
Tidak Tersedia laporan triwulan & $(5)$ \\
lengkap selama periode triwulan I & \\
2013 hingga Triwulan IV 2016 & \\
\hline Bank Umum Syariah memiliki & 6 \\
laporan keuangan yang dibutuhkan & \\
untuk penelitian selama periode & \\
Triwulan I 2013 hingga triwulan IV \\
periode 2016
\end{tabular}

Sample penelitian (triwulan I $2013 \quad 96$
hingga triwulan IV 2016)
Sampel data yang memiliki data (1)
outliner

Sampel penelitian yang digunakan 95

Nama ke enam bank syariah yang menjadi sampel dalam penelitian ini adalah Bank Syariah Mandiri, Bank Muamalat Indonesia, Bank Mega Syariah, Bank BNI Syariah, Bank BRI Syariah dan Bank Panin Syariah..

\section{Statistik Deskriptif}

Tabel 2 Statistik Deskriptif

\begin{tabular}{|c|c|c|c|c|c|}
\hline & \multicolumn{4}{|c|}{ Descriptive Statistics } & \multirow[b]{2}{*}{$\begin{array}{c}\text { Std. } \\
\text { Deviatio } \\
\mathrm{n}\end{array}$} \\
\hline & $\mathrm{N}$ & $\begin{array}{l}\text { Mini } \\
\text { mum }\end{array}$ & $\begin{array}{l}\text { Maxi } \\
\text { mum }\end{array}$ & Mean & \\
\hline PDM & 95 & .022 & 3.559 & .55523 & .546673 \\
\hline $\mathrm{KM}$ & 95 & .100 & .240 & .14674 & .028526 \\
\hline EDPK & 95 & .767 & 1.040 & .89702 & .066417 \\
\hline $\mathrm{RP}$ & 95 & .010 & .070 & .03474 & .014935 \\
\hline PPDB & 95 & -.084 & .034 & .00679 & .046975 \\
\hline I I1VI & 93 & .320 & 1.020 & .61442 & .167882 \\
\hline PDPK & 95 & .670 & .890 & .81653 & .044021 \\
\hline PPAP & 95 & .500 & 1.600 & $\begin{array}{r}1.0349 \\
5\end{array}$ & .153296 \\
\hline
\end{tabular}

\begin{tabular}{lrrrrr}
\hline UB & 95 & 30.0 & 236.0 & 97.011 & 71.2502 \\
BOPO & 95 & .770 & 1.100 & .90663 & .060329 \\
BI & 95 & .057 & .077 & .07020 & .006179 \\
RATE & & & & & \\
Valid N & & & & & \\
(listwise & 95 & & & & \\
) & & & & & \\
\hline Sumber : Data Sekunder yang diolah, 2017
\end{tabular}

Berdasarkan hasil perhitungan dari tabel 2 diatas dapat diketahui bahwa Profit Distribution Management (PDM) dapat diketahui bahwa nilai tertinggi pada bank Mega Syariah dan nilai PDM terendah pada bank Syariah Mandiri.Kecukupan modal (KM) dapat diketahui bahwa nilai $\mathrm{KM}$ tertinggi pada bank Bukopin Syariah, sedangkan nilai KM terendah juga terdapat pada bank Bukopin Syariah. Efektifitas Dana Pihak Ketiga (EDPK) diketahui bahwa nilai EDPK tertinggi pada bank Muamalat Indonesia, sedangkan nilai EDPK terendah pada bank Mega Syariah.Resiko Pembiayaan (RP) diketahui bahwa nilai RP tertinggi pada bank Muamalat Indonesia, sedangkan nilai RP terendah juga pada bank Muamalat Indonesia. Pertumbuhan Produk Domestik Bruto (PPDB) diketahui bahwa nilai PPDB tertinggi pada tahun 2014, sedangkan nilai PPDB terendah pada tahun 2016.

Proporsi Penyisihan Non Investasi (PPNI) diketahui bahwa nilai PPNI tertinggi pada bank BNI Syariah, sedangkan nilai PPNI terendah terdapat pada bank Muamalat Indonesia.

Proporsi Dana Pihak Ketiga (PDPK) diketahui bahwa nilai PPNI tertinggi pada bank Bukopin Syariah, sedangkan nilai PDPK terendah terdapat pada bank Mega Syariah.Penyisihan Penghapusan Aktiva Produktif (PPAP) dapat diketahui nilai PPAP tertinggi pada bank Syariah Mandiri, sedangkan nilai PPAP terendah terdapat pada bank Muamalat Indonesia.Umur Bank (UB) diketahui bahwa nilai UB tertinggi pada bank Muamalat Indonesia, sedangkan nilai UB terendah terdapat pada bank BRI Syariah.Biaya Operasional Pendapatan Operasional (BOPO) diketahui nilai BOPO tertinggi pada bank Mega Syariah, sedangkan nilai BOPO terendah terdapat juga pada bank Mega Syariah.BIrate diketahui 
nilai BIrate tertinggi pada triwulan IV tahun 2014, nilai $\mathrm{Bi}$ rate terendah terdapat pada triwulan I tahun 2013.

\section{Hasil Uji Normalitas}

Berdasarkan hasil uji normalitas menggunakan uji One Sample KolmogorofSmirnov terlihat bahwa nilai Asymp. Sig (2-tailed) sebesar $0,000<0,05$ yang berarti data berdistribusitidak normal sehingga dilakukan transform data Double Log. Berdasarkan hasil uji normalitas menggunakan uji One Sample Kolmogorof-Smirnov, nilai Asymp. Sig (2-tailed) sebesar 0,200 yang berarti lebih besarl dari 0,05. Dari hasiltersebut dapat disimpulkan bahwa data berdistribusi normal.

\section{Hasil Uji Autokorelasi}

Berdasarkan hasil uji run test, diketahui nilai asymp. Sig (2-tailed) sebesar 0,354 yang berati lebih besar dari 0, 05. Oleh karena itu dapat dipastikan bahwa model regresi linier berganda tersebut tidak terjadi gejala autokorelasi.

\section{Hasil Uji Multikolonierietas}

\section{Tabel 3 Hasil Uji Multikolinearitas}

\begin{tabular}{|c|c|c|c|c|c|c|c|c|}
\hline \multicolumn{9}{|c|}{ Coefficients $s^{2}$} \\
\hline & & \multicolumn{2}{|c|}{ Unstantariced Crefficients } & \multirow{2}{*}{$\begin{array}{c}\begin{array}{c}\text { Standariced } \\
\text { Coeficents }\end{array} \\
\text { Beta }\end{array}$} & \multirow[b]{2}{*}{$t$} & \multirow[b]{2}{*}{ sig } & \multicolumn{2}{|c|}{ Colivearty Satisits } \\
\hline \multicolumn{2}{|c|}{ Wndal } & B & Strid Eme & & & & $\begin{array}{l}\text { Tolerance } \\
\text { Then }\end{array}$ & WF \\
\hline 1 & Censtants & 5.182 & 2809 & & 1.845 & .059 & & \\
\hline & $B M$ & 3638 & 1978 & 190 & 1.649 & 6.9 & 783 & 1.278 \\
\hline & EDPK. & -1.612 & 1013 & -196 & -1.591 & .115 & 550 & 1.617 \\
\hline & QP & $\$ 113$ & 5.659 & -.112 & -613 & .418 & .437 & $229:$ \\
\hline & PPOB & -25619 & 14929 & -196 & -1.716 & .090 & 639 & 1.568 \\
\hline & PPNI & 1371 & 387 & 421 & 3.545 & .001 & 591 & 1.691 \\
\hline & POPK. & -2722 & 1.391 & .219 & -1.959 & .054 & 665 & 1.504 \\
\hline & PPAP & $-2 n z$ & 352 & -.958 & -589 & 567 & .857 & $1.16 \mathrm{t}$ \\
\hline & U日 & 012 & 201 & 266 & 2326 & .022 & 635 & 1.574 \\
\hline & BOPO & 972 & 1.777 & 107 & 626 & .411 & 494 & 2025 \\
\hline & GRATE & -10233 & 9.937 & -116 & -1.092 & 306 & 661 & 1.514 \\
\hline
\end{tabular}

Berdasarkan uji multikolinearitas, hasil perhitungan menunjukkan bahwa semua variabel bebas mempunyai nilai tolerance > $>, 10$. Berdasarkan hasil nilai VIF juga menunjukan hal yang sama tidak ada satupun variabel independen yang memiliki nilai VIF lebih dari 10 . Berdasarkan Coeffiicients pada gambar pada tabel dapat diketahui nilai VIF adalah 1,278 (Variabel KM), 1,817 (Variabel EDPK), 2,291 (Variabel RP), 1,566 (Variabel PPDB), 1,691 (Variabel PPNI), 1,504 (Variabel PDPK), 1,166 (Varibel PPAP), 1,574 (Variabel UB), 2,025
(Variabel BOPO), dan 1,514 (Variabel BI Rate). Sehingga dapat disimpulkan bahwa model regresi pada penelitian ini tidak terjadi mutikolinearitas dan model layak digunakan.

\section{Hasil Uji Heteroskedastisitas}

Uji heteroskedastisitas dilakukan dengan uji Glejtser dimana hasilnya menunjukkan bahwa pengaruh variable-variabel independen terhadap variable dependen yang berupa nilai absolute dari residualnya tidak signifikan(signifikasinya $>0,05$ ), sehingga tidak ada heteroskedastisitas dalam model regresi.

\section{Hasil Uji Hipotesis}

\section{Tabel 4 Hasil Uji t}

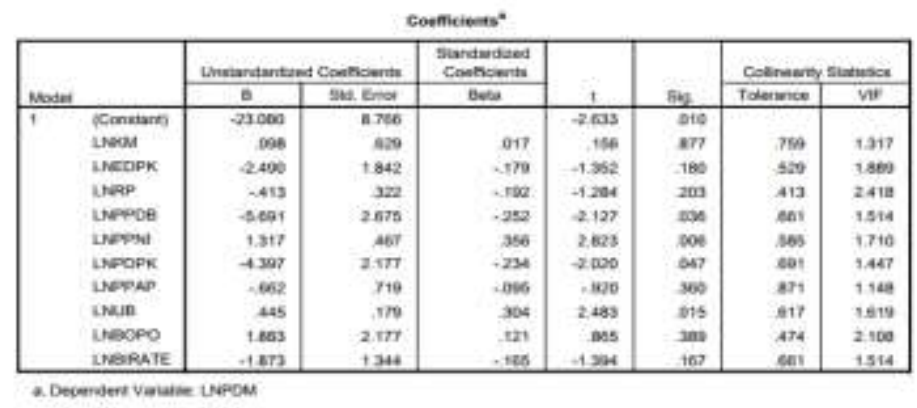

Berdasarkan tabel diatas, dapat disusun persamaan regresi linier berganda sebagai berikut: $\mathrm{Y}=-23,080+0,098 \mathrm{KM}-2,490 \mathrm{EDPK}-0,413$ $\mathrm{RP}-5,691 \mathrm{PPDB}+1,317 \mathrm{PPNI}-4,397 \mathrm{PDPK}-$ $0,662 \mathrm{PPAP}+0,445 \mathrm{UB}+1,883 \mathrm{BOPO}-1,873$ BIRATE

\section{Hasil Uji Koefisien Determinasi $\left(\mathbf{R}^{2}\right)$}

\section{Tabel 5 Hasil Uji Koefisien Determinasi}

Model Summary
\begin{tabular}{|l|c|r|c|c|r|}
\hline Model & R & R Square & $\begin{array}{c}\text { Adjusted R } \\
\text { Square }\end{array}$ & $\begin{array}{c}\text { Std Error of the } \\
\text { Estimate }\end{array}$ & Durbin-Watson \\
\hline 1 & $.548^{\mathrm{a}}$ & .300 & 217 & .483891 & 2.081 \\
\hline
\end{tabular}

a. Predictors: (Constant), BIRATE, PDPK, RP, PPN, PPAP, KM, PPDB, UB, EDPK, BOPO b. Dependent Variable: PDM

Berdasarkan tabel 5 nilai Adjusted $R$ Square sebesar 0,217 atau 21,7 \%. Hal ini menunjukkan bahwa KM, EDPK, RP, PPNI, PPDB, PDPK, PPAP, UB, BOPO, dan BIRATE berpengaruh terhadap Profit Distribution Management sebesar $21,7 \%$ sedangkan sisanya $78,3 \%$ dijelaskan oleh variable lain diluar model. 


\section{Jurnal Ilmiah Ekonomi Islam, 5(03), 2019, 255}

\section{Pengaruh Kecukupan Modal terhadap Profit} Distribution Management

Hipotesis pertama menguji Kecukupan Modal (KM) terhadap Profit Distribution Management (PDM) diperoleh nilai $\mathrm{t}$ hitung $0,156<1,988 \mathrm{t}$ tabel dan nilai signifikan sebesar $0,877>0,05$. Hal ini mengidentifikasi $\mathrm{H} 1$ ditolak Artinya tidak ada pengaruh yang signifikan Kecukupan Modal (KM) terhadap Profit Distribution Management (PDM) bank umum Syariah di Indonesia periode 2013-2016.

Kecukupan modal menggambarkan kemampuan bank baik dalam mempertahankan modal yang mencukupi untuk menutup resiko kerugian yang mungkin timbul dan penanaman dana dalam asset produktif yang mengandung resiko, serta untuk pembiayaan dalam asset tetap dan investasi. Untuk menghitung variable kecukupan modal ini dapat menggunakan Capital Adequancy Ratio (CAR) (Muhammad, 2009 dalam Mulyo dan Mutmainah, 2013). Semakin besar rasio ini, maka kesehatan bank dikatakan membaik. Hal ini dikarenakan besar modal yang dimiliki bank mampu menutupi resiko, serta dapat digunakan untuk pembiayaan penanaman dalam asset tetap dan investasi. Berdasarkan ketentuan Bank for International Settlements, bank yang dinyatakan bank sehat harus memiliki CAR paling sedikit 8\% (Muhammad, 2005 dalam Mulyo dan Mutmainah, 2013). Jika dikaitkan dengan teori stakeholder bank Syariah akan meningkatkan PDM yang mengacu pada suku bunga untuk memuaskan deposan. Hasil penelitian menunjukkan bahwa Kecukupan Modal (KM) tidak berpengaruh signifikan terhadap Profit Dsitribution Management (PDM). Hal ini dapat dilihat pada uji hipotesis dimana variable kecukupan modal signifikan pada 0,867 dan nilai $t$ hitung sebesar 0,156. Tingkat signifikan yang digunakan pada penelitian ini sebesar 5\% (0,05) yang berarti 0,156>0, 05 .

Dengan demikian penelitian ini bertentangan dengan penelitian Kartika dan Adityawarman (2012) serta penelitian Mulyo dan Mutmainah (2013) yang menyatakan bahwa Kecukupan Modal berpengaruh terhadap Profit Distribution
Management. Akan tetapi penelitian ini sejalan dengan penelitian Masruroh (2016), Wibowo dan Syaichu (2013), yang menyatakan bahwa Kecukupan Modal tidak berpengaruh terhadap Profit Distribution Management.

Berdasarkan hasil penelitian dan penjelasan diatas disimpulkan bahwa semakin tinggi kecukupan modal, maka tidak dapat menjadi tolak ukur perbankan Syariah dalam melakukan aktivitas Profit Distribution Management. Dengan kata lain kemampuan bank dalam memiliki modal yang cukup tinggi tidak merupakan factor utama yang menyebabkan kenaikan Profit Distribution Management.

Bank Syariah yang menghasilkan laba yang tinggi tidak berasal dari modal yang besar melainkan upaya dari bank Syariah dalam menjaga kondisi kecukupan modal bank Syariah itu sendiri serta menjaga tingkat bagi hasil yang dikeluarkan dapat berjalan secara stabil tanpa bank Syariah mengeluarkan pendanaan yang dapat memberikan resiko yang besar.

Hasil penelitian ini juga didukung dengan bukti empiris pada sampel Perbankan Syariah yang digunakan dalam penelitian ini yang menggambarkan bahwa kecukupan modal yang tinggi cenderung tidak melakukan aktifitas bagi hasil yang tinggi. Bank Bukopin Syariah pada tahun 2013 memiliki kecukupan modal yang tinggi akan tetapi aktifitas bagi hasil yang di dapatkan deposan rendah. Sedangkan Bank Syariah Mandiri pada tahun 2014 memiliki kecukupan modal yang lebih rendah dari Bank Bukopin Syariah akan tetapi melakukan aktifitas bagi hasil yang didapatkan deposan lebih tinggi dari pada Bank Bukopin Syariah.

\section{Pengaruh Efektifitas Dana Pihak Ketiga terhadap Profit Distribution Management}

Hipotesis kedua menguji pengaruh Efektifitas Dana Pihak Ketiga (EDPK) terhadap Profit Distribution Management diperoleh hasil nilau $\mathrm{t}$ hitung $-1,352<1,988 \mathrm{t}$ tabel dan nilai signifikan sebesar $0,180>0,050$. Hal ini mengidentifikasi $\mathrm{H} 2$ ditolak. Artinya tidak ada pengaruh signifikan Efektifitias Dana Pihak Ketiga (EDPK) terhadap terhadap Profit 
Distribution Management (PDM) pada bank umum Syariah di Indonesia periode 2013-2016.

Efektifitas dana pihak ketiga merupakan cerminan dari fungsi intermediasi bank yaitu dalam menyalurkan dana pihak ketiga ke pembiayaan. Semakin tinggi rasio ini, semakin baik tingkat kesehatan bank, karena pembiayaan yang disalurkan bank lancar, sehingga pendapat bank semakin meningkat.

Mempertahankan likuiditas yang tinggi akan memperlancar costumer reliantship tetapi tingkat bagi hasil akan menurun karena banyaknya dana yang menanggur. Dilain likuiditas yang rendah menggambarkan kurang baiknya posisi likuiditas suatu bank. Karena itu apabila efektifitas dana pihak ketiga di ukur dengan rasio FDR semakin tinggi, maka bagi hasil akan semakin tinggi juga.

Apabila hal ini dikaitkan dengan teori stakeholder, maka bank Syariah akan mengurangi tingkat Profit Distribution Management yang mengacu pada suku bunga. Berkurangnyatingkat Profit Distribution Management dikarenakan bank telah mampu memanage deposannya dengan tingkat profit distribution yang sudah tinggi. Hasil penelitian menunjukkan bahwa Efektifitas Dana Pihak Ketiga tidak berpengaruh terhadap Profit Distribution Management. Hal ini dapat dilihat pada uji hipotesis dimana variable efektifitas dana pihak ketiga signifikan pada 0,180 dan nilai t hitung sebesar $-1,352$.

Tingkat signifikan yang digunakan pada penelitian ini sebesar 5\% $(0,05)$ yang berarti $0,180>0$, 05.Dengan demikian penelitian ini bertentangan dengan penelitian Kartika dan Adityawarman (2012) serta penelitian Mulyo dan Mutmainah (2013) yang menyatakan bahwa Efektifitas Dana Pihak Ketiga berpengaruh signifikan terhadap Profit Distribution Management. Akan tetapi penelitian ini sejalan dengan penelitian Masruroh (2016) dan Wafaretta et al., (2015) yang menyatakan bahwa Efektifitas Dana Pihak Ketiga tidak berpengaruh signifikan terhadap Profit Distribution Management.

Berdasarkan hasil penelitian dan penjelasan diatas dapat disimpulkan, semakin tinggi besar efektifitas dana pihak ketiga, maka tidak dapat menjadi tolak ukur perbankan Syariah dalam melakukan aktivitas Profit Distribution Management. Dengan kata lain perbankan Syariah mempertahankan jumlah likuiditas yang tinggi mengakibatkan menurunnya tingkat bagi hasil yang dibagikan kepada deposan dikarenakan banyaknya banyak mengganggur. Hasil ini juga didukung dengan bukti empiris pada sampel Perbankan Syariah yang digunakan dalam penelitian ini yang menggambarkan bahwa efektifitas dana pihak ketiga yang cenderung tinggi mengakibatkan tingkat bagi hasil yang rendah untuk deposan. Bank Syariah Mandiri pada tahun 2014 memliki kencenderungan tingkat efektifitas dana pihak ketiga yang tinggi akan tetapi aktifitas bagi hasil yang didapatkan deposan cenderung rendah. Sedangkan Bank Mega Syariah pada tahun 2013 memiliki kecenderungan tingkat efektifitas dana pihak ketiga yang rendah dari Bank Syariah Mandiri akan tetapi aktifitas bagi bagi hasil yang didapatkan deposan lebih tinggi.

\section{Pengaruh Resiko Pembiayaan terhadap Profit Distribution Management.}

Hipotesis ketiga menguji pengaruh Resiko Pembiayaan (RP) terhadap Profit Distribution Management diperoleh hasil nilau $\mathrm{t}$ hitung $1,284<1,988 \mathrm{t}$ tabel dan nilai signifikan sebesar $0,203>0,050$. Hal ini mengidentifikasi H3 ditolak. Artinya tidak ada pengaruh signifikan Resiko Pembiayaan (RP) terhadap terhadap Profit Distribution Management (PDM) pada bank umum Syariah di Indonesia periode 20132016.

Resiko pembiayaan digunakan untuk mengukur tingkat permasalahan pembiayaan yang dihadapi oleh bank Syariah. Untuk mengukur resiko pembiayaan dapat menggunakan Non Performing Financing. Rasio ini merupakan rasio untuk mengukur kemampuan bank dalam menjaga resiko kegagalan pengambilan kredit oleh debitur. Semakin tinggi rasio ini, menunjukkan kualitas pembiayaan bank Syariah yang semakin buruk. Bank Indonesia melalui Surat Edaran Bank Indonesia No. 
6/23/DPNP tanggal 31 Mei 2014 menetapkan kriteria rasio NPF yang ideal di bawah $6 \%$.Semakin baik kualitas pembiayaan yang disalurkan bank, semakin kecil tingkat NPF. Apabila resiko pembiayaan semakin besar, maka bagi hasil semakin kecil. Bila dikaitkan dengan teori stakeholder, maka bank Syariah akan menaikan tingkan Profit Distribution Management yang mengacu pada sukubunga untuk memuaskan / memanage deposannya. Bertambahnya tangkat Profit Distribution Management dikarenakan tingkat profit distribution yang diperoleh deposan sudah renah. Hasil penelitian menunjukkan bahwa variable Resiko Pembiayaan tidak berpengaruh signifikan terhadap Profit Distribution Management. Hal ini dapat dilihat pada uji hipotesis dimana variable resiko pembiayaan signifikan pada 0,203 dan nilai t hitung sebesar $-1,284$. Tingkat signifikan yang digunakan pada penelitian ini sebesar $5 \%$ $(0,05)$ yang berarti $0,203>0,05$.

Dengan demikian penelitian ini sejalan dengan penelitian Mulyo dan Mutmainah (2013), Wibowo dan Syaichu (2013) serta Andreany (2011) yang menyatakan bahwa Resiko Pembiayaan tidak berpengaruh signifikan terhadap Profit Distribution Management. Dengan demikian berdasarkan hasil dan penjelasan diatas dapat disimpulkan bahwa semakin tinggi tingkat resiko pembiayaan tidak dapat menjadi tolak ukur perbankan Syariah dalam proses aktifitas Profit Distribution Management. Dengan kata lain apabila perbankan Syariah memiliki tingkat resiko pembiayaan yang tinggi akan mengakibatkan menurunya aktifitas bagi hasil dikarenakan kualitas pembiayaan yang buruk dan tingkat kesehatan perbankan Syariah yang buruk.

Hasil penelitian ini juga didukung dengan bukti empiris pada sampel Perbankan Syariah yang digunakan dalam penelitian ini yang menggambarkan bahwa resiko pembiaayaan yang cenderung tinggi mengakibatkan tingkat bagi hasil yang rendah untuk deposan. Bank Mandiri Syariah pada tahun 2015 memiliki kualitas pembiayaan yang tinggi yang mengakibatkan aktifitas bagi hasil yang rendah. Akan tetapi Bank BNI Syariah pada tahun 2016 memiliku kualitas pembiayaan yang rendah mengakibatkan aktifitas bagi hasil yang tinggi kepada deposan.

\section{Pengaruh Pertumbuhan Produk Domestik}

\section{Bruto terhadap Profit Distribution Management.}

Hipotesis keempat menguji pengaruh Pertumbuhan Produk Domestik Bruto (PPDB) terhadap Profit Distribution Management diperoleh hasil nilau $\mathrm{t}$ hitung $-2,127>1,988 \mathrm{t}$ tabel dan nilai signifikan sebesar $0,036<0,05$ sehingga H4 diterima. Artinya ada pengaruh signifikan Pertumbuhan Produk Domestik Bruto (PPDB) terhadap terhadap Profit Distribution Management (PDM) pada bank umum Syariah di Indonesia periode 2013-2016. Kondisi perekonomian dapat tercemin melalui pertumbuhan domestik bruto. Kondisi perekonomian yang baik menandakan kegiatan produksi dalam negeri sehat terceminkan oleh PDB di setiap waktu. Pada kondisi tersebut masyarakat sebagai pemilik faktor produksi secara agregat akan memperoleh pendapatan yang lebih besar. Pendapatan yang lebih besar ini akan berdampak baik terhadap kondisi keuangan bank. Ketika terjadi hal yang sebaliknya yaitu kondisi perekonomian negara yang buruk seperti resesi, maka akan terjadi peningkatan tingkat pengangguran dan penurunan pertumbuhan bisnis. Dalam resesi terdapat kemungkinan bahwa individu maupun pebisnis akan kesulitan atau bahkan tidak mampu memenuhi kewajiban membayar hutang kepada bank (Farook et al., 2009). Bila dikaitkan dengan teori stakeholder dimana bank harus memanage deposannya, maka bank harus mamanage deposannya, maka bank Syariah akan mengorbankan laba mereka sendiri atau bahkan modal pemegang saham untuk mempertahankan competitive return kepada Invesment Account Holder. Hasil penelitian menunjukkan bahwa variable Pertumbuhan Produk Domestik Bruto berpengaruh signifikan terhadap Profit Distribution Management. Hal ini dapat dilihat pada uji hipotesis dimana variable resiko pembiayaan signifikan pada 0,036 dan 
nilai $\mathrm{t}$ hitung sebesar $-2,127$. Tingkat signifikan yang digunakan pada penelitian ini sebesar $5 \%$ $(0,05)$ yang berarti $0,036<0,05$.

Dengan demikian penelitian ini bertentangan dengan penelitian Farook et al., (2009) dan penelitian Mulyo dan Mutmainah (2013) yang menyatakan bahwa Pertumbuhan Produk Domestik Bruto tidak berpengaruh signifikan terhadap Profit Distribution Management.Dengan demikian berdasarkan hasil penelitian dan penjelasan diatas dapat disimpulkan bahwa semakin besar pertumbuhaan ekonomi suatu negara, semakin besar pula kondisi perekonomian suatu negara tersebut yang menandakan kondisi dalam negeri sehat. Sebaliknya apabila semakin rendah pertumbuhan ekonomi suatu negara, semakin buruk pula kondisi perekonomian suatu negara tersebut sehingga menimbulkan keadaan seperti resesi dan tingkat pengganguran yang tinggi.

Hasil penelitian ini juga didukung dengan bukti empiris pada Perbankan Syariah yang digunakan dalam penelitian ini yang menggambarkan bahwa pertumbuhaan produk domestic bruto yang cenderung tinggi mengakibatkan aktifitas tingkat bagi hasil yang tinggi untuk deposan. Tingkat produk domestik bruto di Indonesia tertinggi terjadi pada tahun 2016 sebagai contoh terjadi pada bank Mega Syariah, dengan tingkat PDB tinggi menyebabkan aktifitas bagi hasil juga tinggi. Sedangkan tingkat produk bruto terendah terjadi pada tahun 2014 sebagai contoh terdapat pada bank Bank Muamalat Indonesia, dengan tingkat PDB rendah menyebabkan aktifitas bagi hasil yang rendah.

\section{Pengaruh Proposi Pembiayaan Non Investasi terhadap Profit Distribution Management.}

Hipotesis kelima menguji pengaruh Proporsi Pembiayaan Non Investasi (PPNI) terhadap Profit Distribution Management diperoleh hasil nilau $\mathrm{t}$ hitung 2,823 > 1,988 t tabel dan nilai signifikan sebesar $0,006<0,050$. Hal ini mengidentifikasi H5 diterima. Artinya ada pengaruh signifikan Proporsi Pembiayaan Non Investasi (PPNI) terhadap terhadap Profit
Distribution Management (PDM) pada bank umum Syariah di Indonesia periode 2013-2016. Proporsi pembiayaan non investasi bank Syariah mengacu pada tingkat tetap (sisi piutang). Pembiayaan non investasi pada bank Syariah dilakukan dengan akad Murabahah, Salam, Isthiana dan Ijarah. Pembiayaan jenis ini menggunakan harga dan keuntungan yang disepakati di awal kontrak. Selama kontrak ini berjalan dan pembayaran diangsur, waktu semakin berjalan. Saat berjalannya waktu, terdapat kemungkinan terjadi perubahan tingkat suku bunga, sehingga bank Syariah berhadapan dengan fund gap antara asset returns yang sudah ditetapkan di awal kontrak dengan dana deposan yang digunakan untuk proses pembiayaan non investasi tersebut.

Besarnya proposi pembiayaan non investasi menentukan tingkat dimana bank Syariah melakukan Profit Distribution Management untuk return mismatch dalam keadaan pasar dimana terdapat perubahaan suku bunga (Farook et al., 2009). Oleh karena itu, semakin tinggi tingkat rasio, semakin tinggi tingkat Profit Distribution Management. Hasil penelitian menunjukkan bahwa variabel Proporsi Pembiayaan Non Investasi berpengaruh signifikan terhadap Profit Distribution Management. Hal ini dapat dilihat pada uji hipotesis dimana variable resiko pembiayaan signifikan pada 0,006 dan nilai t hitung sebesar 2,823. Tingkat signifikan yang digunakan pada penelitian ini sebesar 5\% $(0,05)$ yang berarti 0,006<0,05.Dengan demikian penelitian ini konsisten dengan penelitian Farook et al., (2009) serta penelitian Mulyo dan Mutmainah (2013), yang menyatakan bahwa variabel proporsi pembiayaan non investasi berpengaruh signifikan terhadap Profit Distribution Management.

Berdasarkan uraian hasil penelitian dan penjelasan diatas dapat disimpulkan bahwa semakin tinggi tingkat pembiayaan non investasi maka semakin tinggi aktifitas bagi hasil. Dengan kata lain apabila tingkat pembiayaan non investasi tinggi akan menentukan tingkat dimana bank Syariah melakukan Profit Distribution 
Management untuk return mismatch dalam keadaan pasar dimana terdapat perubahan suku bunga. Perubahan suku bunga yang sangat di kwatirkan oleh deposan oleh karena itu pembiayaan non investasi ini menjaga agar tidak menyebabkan perubahaan suku bunga yang tinggi.Hasil penelitian ini juga didukung dengan bukti empiris pada sampel Perbankan Syariah yang digunakan dalam penelitian ini yang menggambarkan bahwa variable peembiayaan non investasi yang cenderung tinggi mengakibatkan aktifitas tingkat bagi hasil yang tinggi untuk deposan. Bank BNI Syariah pada tahun 2016 memiliki pembiayaan non investasi tertinggi pada penelitian menyebabkan aktifitas bagi hasil yang tinggi juga. Sedangkan Bank Muamalat memiliki pembiayaan non investasi yang cederung rendah, sehingga menyebabkan aktifitas bagi hasi yang rendah.

\section{Pengaruh Proporsi Dana Pihak Ketiga terhadap Profit Distribution Management.}

Hipotesis keenam menguji pengaruh Proporsi Dana Pihak Ketiga (PDPK) terhadap Profit Distribution Management pada bank umum Syariah di Indonesia periode 2013-2016. Diperoleh hasil nilau $\mathrm{t}$ hitung $-2,020>1,988 \mathrm{t}$ tabel dan nilai signifikan sebesar $0,047<0,050$. Hal ini mengidentifikasi H6 diterima. Artinya ada pengaruh signifikan Proporsi Dana Pihak Ketiga (PDPK) terhadap terhadap Profit Distribution Management (PDM) pada bank umum Syariah di Indonesia periode 2013-2016.

Rinaldy (2008) dalam Kartika (2012) mengatakan bahwa pertumbuhan bank Syariah sangat dipengaruhi oleh kemampuannya dalam menghimpun dana masyarakat. Tanpa dana yang cukup, bank tidak dapat melaksanakan fungsinya dengan maksimal ataupun bahkan menjadi tidak berfungsi. Proporsi dana pihak ketiga merupakan variable yang menggambarkan seberapa besar ketergantungan bank terhadap dana deposan. Semakin tinggi dana pihak ketiga yang dimiliki bank, bank mempunyai cukup dana untuk menyalurkan ke pembiayaan yang dapat menghasilkan profibilitas. Profibiltas bank tinggi maka profit distribution bank akan meningkat.
Hasil penelitian menunjukkan bahwa variable Proporsi Dana Pihak Ketiga berpengaruh signifikan terhadap Profit Distribution Management. Hal ini dapat dilihat pada uji hipotesis dimana variable resiko pembiayaan signifikan pada 0,047 dan nilai t hitung sebesar 2,020. Tingkat signifikan yang digunakan pada penelitian ini sebesar $5 \%(0,05)$ yang berarti $0,047<0,05$.

Hasil ini sejalan dengan penelitian Mulyo dan Mutmainah (2013), Wafaretta et al.,(2015), yang menyatakan bahwa Proporsi Dana Pihak Ketiga berpengaruh signifikan terhadap Profit Distribution Management.

Berdasarkan hasil penelitian dan penjelasan dapat disimpulkan semakin tinggi proporsi dana pihak ketiga mengindikasi aktifitas bagi hasil tinggi. Peningkatan atau penurunan Proporsi Dana Pihak Ketiga selama periode penelitian mempengaruhi Profit Distribution Management. Sehingga tinggi Dana Pihak Ketiga yang berhasil dihimpun oleh perbankan Syariah, akan mendorong peningkatan jumlah pembiayaan yang disalurkan, perbankan Syariah menyediakan Profit Distrinbution Management yang bersifat konsisten sesuai dengan asset returns yang diperoleh. Hasil penelitian ini juga didukung dengan bukti empiris pada sampel Perbankan Syariah yang digunakan dalam penelitian ini yang menggambarkan bahwa variable proprosi dana pihak ketiga yang cenderung tinggi mengakibatkan aktifitas tingkat bagi hasil yang tinggi untuk deposan. Bank Bukopin Syariah pada tahun 2016 menujukkan bahwa tingkat dana pihak ketiga yang tinggi, menyebabkan aktifitas bagi hasil yang tinggi. Sedangkan pada bank BNI Syariah tahun 2014 menunjukkan tingkat dana pihak ketiga yang rendah, sehingga menyebabkan aktifitas bagi hasil yang rendah ke deposan.

\section{Pengaruh Penyisihan Penghapusan Aktiva Produktif terhadap Profit Distribution Management}

Hipotesis ketujuh menguji pengaruh Penyisihan Penghapusan Aktiva Produktif (PPAP) terhadap Profit Distribution Management pada bank umum Syariah di Indonesia periode 2013- 
2016. Diperoleh hasil nilau t hitung - 0,952 < $1,988 \mathrm{t}$ tabel dan nilai signifikan sebesar $0,360>$ 0,050. Hal ini mengidentifikasi $\mathrm{H} 7$ ditolak. Artinya tidak ada pengaruh signifikan Penyisihan Penghapusan Aktiva Produktif (PPAP) terhadap terhadap Profit Distribution Management (PDM) pada bank umum Syariah di Indonesia periode 2013-2016. Bank memiliki kebijakan cadangan, kebijakan tersebut mengacu pada penyisihan kerugian. Bank Syariah memiliki kecenderungan untuk membentuk penyisihan kerugian untuk menyerap kerugian di masa depan (Boulila et al., 2010 dalam Mulyo dan Mutmainah, 2013). Besarnya penyisihan dalam batasan tertentu ditentukan oleh Bank Indonesia, namun pihak manajemen bank masih diberikan kelelusaan untuk menentukan kualitas asset berdasarkan ketentuan yang diatur dalam PBI tersebut serta membentuk cadangan PPAP melebihi cangan yang wajib dibentuk. Oleh karenanya seringkali PPAP dijadikan objek oleh manajer dalam melakukan manipulasi laba (Tobing dan Anggorowati, 2009 dalam Mulyo dan Mutmainah, 2013).

Konsekuensinya PPAP ini mendorong bank untuk lebih berani dalam mengambil resiko dalam melakukan pembiayaan karena tahu bahwa profit distribution ke nasabah terlindungi. Terdapat kemungkinan bahwa bank Syariah lebih nyaman melakukan PDM jika terdapat cadangan tersebu (Farook et al., 2009). Hasil penelitian menunjukkan bahwa variable Pengaruh Penghapusan Aktiva Produktif tidak berpengaruh signifikan terhadap Profit Distribution Management. Hal ini dapat dilihat pada uji hipotesis dimana variable resiko pembiayaan signifikan pada 0,360 dan nilai $\mathrm{t}$ hitung sebesar -0,952. Tingkat signifikan yang digunakan pada penelitian ini sebesar $5 \%(0,05)$ yang berarti $0,360>0,05$.

Hal ini bertentangan dengan penelitian Mulyo dan Mutmainah (2013) yang menyatakan bahwa Penyisihan Penghapusan Aktiva Produktif berpengaruh signifikan Profit Distribution Management. Akan tetapi konsisten dengan penelitian dan Muyassaroh (2015), yang menyatakan bahwa Penyisihan Penghapusan Aktiva Produktif tidak berpengaruh signifikan dengan Profit Distribution Management. Berdasarkan hasil penelitian dan penjelasan diatas dapat disimpulkan bahwa semakin tinggi PPAP tidak mengindikasi aktifitas profit distribution management semakin tinggi. Hal ini umumnya karena cadangan yang dimiliki Bank Umum Syariah tidak begitu tinggi dengan nilai rata-rata hanya sebesar $1,03 \%$ sehingga tidak mampu menutupi resiko kerugian yang timbul dari pendanaan. Dengan kata lain bahwa PPAP yang tinggi dapat mengakibatkan aktifitas Profit Distribution Management yang tinggi maupun rendah.

Hasil penelitian ini juga didukung dengan bukti empiris pada sampel Perbankan Syariah yang digunakan dalam penelitian ini yang menggambarkan bahwa variable Penyisihan penghapusan aktiva produktif yang cenderung tinggi mengakibatkan aktifitas tingkat bagi hasil yang tinggi maupu rendah untuk deposan. Sebagai contoh untuk bank BNI Syariah yang memiliki tingkat PPAP yang sama pada 2013 dan tahun 2014 memiliki hasil aktifitas bagi hasil yang lebih tinggi di tahun 2013 sedangkan pada tahun 2014 lebih rendah. Selanjutnya pada bank BRI Syariah dengan kasus yang sama memiliki tingkat PPAP yang sama pada tahun 2014 dan 2015 memiliki hasil aktifitas bagi hasil yang lebih tinggi pada tahun 2014 sedangkan pada tahun 2015 lebih rendah.

\section{Pengaruh Umur Bank terhadap Profit Distribution Management.}

Hipotesis kedelapan menguji pengaruh Umur Bank (UB) terhadap Profit Distribution Management pada bank umum Syariah di Indonesia periode 2013-2016. Diperoleh hasil nilau $\mathrm{t}$ hitung 2,483>1,988 $\mathrm{t}$ tabel dan nilai signifikan sebesar $0,015<0,050$. Hal ini mengidentifikasi $\mathrm{H} 8$ diterima.

Artinya ada pengaruh signifikan Umur Bank (UB) terhadap terhadap Profit Distribution Management (PDM) pada bank umum Syariah di Indonesia periode 2013-2016.. Farook et al., (2009) berpendapat bahwa susah bagi perusahaan 
untuk memulai operasi usahanya terutama mendapatkan laba di awal-awal tahun operasinya. Bagi bank Syariah ini merupakan hal yang buruk terutama karena penggunaan sistemn bagi hasil. Susahnya mendapatkan laba akan membuat hasil semakin kecil, hal ini akan mengakibatkan deposan menarik dananya dan memindahkan pada bank yang memberikan retur lebih baik (displacement fund). Hasil penelitian menunjukkan bahwa variable Umur Bank berpengaruh signifikan terhadap Profit Distribution Management. Hal ini dapat dilihat pada uji hipotesis dimana variable resiko pembiayaan signifikan pada 0,015 dan nilai $\mathrm{t}$ hitung sebesar $-2,483$. Tingkat signifikan yang digunakan pada penelitian ini sebesar $5 \%(0,05)$ yang berarti $0,015<0,05$.

Hal ini bertentangan dengan penilitian Farook et al., (2009) serta penelitian Mulyo dan Mutmainah (2013) yang menyatakan bahwa Umur bank tidak berpengaruh signifikan terhadap Profit Distribution Management. Akan tetapi konsisten dengan penelitian Muyassaroh (2015) yang menyatakan bahwa Umur bank berpengaruh terhadap Profit Distribution Management.Berdasarkan hasil penelitian dan penjelasan diatas dapat disimpulkan bahwa Bank Umum Syariah yang telah berumur lebih lama maupun baru dapat dijadikan dasar dalam pemberian bagi hasil deposan.

Hal ini disebabkan bahwa umur bank dapat dilihat dari record bank tersebut. Bank yang memiliki umur lama akan mendapatkan lebih kepercayaan dengan hasil-hasil yang ditunjukkan sedangkan bank baru akan berlomba-lomba menunjukan kredibilitasnya. Mampu atau tidaknya perbankan Syariah meyakinkan deposan. Hasil penelitian ini juga didukung dengan bukti empiris pada sampel Perbankan Syariah yang digunakan dalam penelitian ini yang menggambarkan bahwa variable umur bank yang cenderung lama mengakibatkan aktifitas tingkat bagi hasil yang tinggi untuk deposan. Bank Mualamat Indonesia adalah bank yang paling lama diantara bank bank Syariah di Indonesia. Pada tahun 2016 menujukkan bahwa aktifitas bagi hasil yang dihasil paling tertinggi diantara bank yang lain. Sedangkan bank BNI Syariah yang terhitung paling baru pada tahun 2014 menujukkan bahwa aktifitas bagi hasil yang rendah.

\section{Pengaruh Biaya Operasional Pendapatan Operasional terhadap Profit Distribution Management}

Hipotesis kesembilan menguji pengaruh Biaya Operasional Pendapatan Operasional (BOPO) terhadap Profit Distribution Management pada bank umum Syariah di Indonesia periode 2013-2016. Diperoleh hasil nilau $\mathrm{t}$ hitung $0,865<1,988 \mathrm{t}$ tabel dan nilai signifikan sebesar 0,471> 0,050. Hal ini mengidentifikasi H9 ditolak. Artinya tidak ada pengaruh signifikan Biaya Operasional Pendapatan Operasional (BOPO) terhadap terhadap Profit Distribution Management (PDM) pada bank umum Syariah di Indonesia periode 2013-2016. Rasio BOPO merupakan rasio yang menunjukkan besaran perbandingan antara beban atau biaya operasional terhadap pendapatan operasional suatu perusahaan pada periode tertentu. BOPO telah menjadi salah satu rasio yang perubahan nilainnya sangat diperhatikan terutama bagi sector perbankan mengingat salah saru kriteria penetuan tingkat kesehatan bank oleh Bank Indonesia adalah besaran rasio ini. Bank yang efisien dalam menekan biaya operasionalnya akan dapat mengurangi kerugian akibat ketidakefisienan bank dalam mengelola usahanya. Sehingga laba juga akan meningkat. Dengan meningkatnya laba yang diperoleh perusahaan maka tingkat bagi hasil yang diberikan akan semakin tinggi begitu pula sebaliknya. Hasil penelitian menunjukkan bahwa variabel Biaya Operasional Pendapatan Operasional (BOPO) tidak berpengaruh signifikan terhadap Profit Distribution Management. Hal ini dapat dilihat pada uji hipotesis dimana variable resiko pembiayaan signifikan pada 0,471 dan nilai t hitung sebesar 0,865 . Tingkat signifikan yang digunakan pada penelitian ini sebesar $5 \%(0,05)$ yang berarti $0,471>0,05$. 
Hal ini bertentangan dengan penelitian Wibowo dan Syaichu (2013) serta penelitian Musyarooh (2015), yang menyatakan bahwa BOPO berpengaruh terhadap Profit Distribution Management. Akan tetapi sejalan dengan penelitian Masruroh (2016), yang menyatakan bahwa BOPO berpengaruh terhadap Profit Distribution Management. Berdasarkan hasil penelitian dan penjelasan dapat disimpulkan bahwa semakin tinggi biaya operasional pendapatan operasional tidak dapat mengindikasi aktifitas Profit Distribution Management. Dengan kata lain besar atau kecil biaya operasial pendapatan operasional tidak dapat memberikan pengaruh yang signifikan terhadap aktifitas bagi hasil. Hal ini dikarenakan ketidakeifisienan biaya operasional pendapatan operasional dalam megelola usaha perbankan Syariah. Hasil penelitian ini juga didukung dengan bukti empiris pada Perbankan Syariah dalam penelitian ini yang menggambarkan bahwa variabel BOPO yang cenderung tinggi ataupun rendah tidak berpengaruh terhadap aktifitas tingkat bagi hasil yang tinggi untuk deposan.

Bank Muamalat Indonesia pada tahun 2015 dan 2016 memiliki tingkat BOPO yang relative sama akan tetapi pada tahun 2015 lebih besar mempengaruh tingkat Profit Distribution Management, sedangkan pada tahun 2016 lebih rendah. Hal yang sama terjadi pada Bank BNI Syariah di tahun 2013 dan 2015 memiliki tingkat BOPO yang relatif sama akan tetapi aktifitas bagi hasil lebih besar terjadi pada tahun 2015 dibandingkan di tahun 2013.

\section{Pengaruh Bi-rate terhadap Profit Distribution Management.}

Hipotesis kesepuluh menguji pengaruh BIrate terhadap Profit Distribution Management pada bank umum Syariah di Indonesia periode 2013-2016. Diperoleh hasil nilau t hitung - 1,394 $<1,988 \mathrm{t}$ tabel dan nilai signifikan sebesar 0,167 $>0,050$. Hal ini mengidentifikasi H10 ditolak. Artinya tidak ada pengaruh signifikan Bi-rate terhadap terhadap Profit Distribution Management (PDM) pada bank umum Syariah di Indonesia periode 2013-2016.
$\mathrm{BI}$ rate adalah suku bunga kebijakan yang mencerminkan sikap atau stance kebijakan moneter yang ditetapkan oleh Bank Indonesia dan diumumkan kepada public. Sasaran operasional kebijakan modeter dalam mengimplemintasikan BI rate dicerminkan pada perkembangan suku bunga Pasar Uang Antar Bank Overnight. Pergerakan PUAB ini diharakan akan diikuti oleh perkembangan suku bunga deposito, dan pada gilirannya suku bunga kredit perbankan. Bank Indonesia pada umumnya akan menaikkan BI rate apabila inflasi kedepan diperkirakan melampaui sasaran yang akan ditetapkan, sebaliknya Bank Indonesia akan menurunkan BI rate apabila inflasi ke depan diperkirakan berada dibawah sasaran yang telah ditetapkan.

Hasil penelitian menunjukkan bahwa variable $\mathrm{Bi}$ rate tidak berpengaruh signifikan terhadap Profit Distribution Management. Hal ini dapat dilihat pada uji hipotesis dimana variable resiko pembiayaan signifikan pada 0,167 dan nilai t hitung sebesar $-1,394$. Tingkat signifikan yang digunakan pada penelitian ini sebesar 5\% $(0,05)$ yang berarti $0,167>0,05$.

Hal ini sejalan dengan oenelitian Wibowo dan Syaichu (2013) serta penelitian Muyassaroh (2015), yang menyatakan bahwa BI rate tidakberpengaruh signifikan terhadap Profit Distribution Management.Berdesarkan hasil penelitian dan penjelasan diatas dapat di simpulkan bahwa besar rendahnya Bi rate tidak mengindikasi adanya pengaruh terhadap aktifitas Profit Distribition Management. Hal ini dikarenakan besar kecilnya BI rate tidak mengakibatkan melambatnya pertumbuhan sector riil dan laju pertumbuhan ekonomi nasional. Sedangkan pada proses bagi hasil pada perbankan Syariah tergantung kondisi perbankan Syariah itu sendiri.

Hasil penelitian ini juga didukung dengan bukti empiris pada sampel Perbankan Syariah yang digunakan dalam penelitian ini yang menggambarkan bahwa variabel $\mathrm{Bi}$ rate yang cenderung tinggi ataupun rendah tidak berpengaruh terhadap aktifitas tingkat bagi hasil 
yang tinggi untuk deposan. Sebagai contoh pada tahun 2013 dan 2014 relative cenderung posisi bi rate yang sama, pada Bank BNI Syariah membuktikan bahwa aktifitas bagi hasil berbeda. Pada tahun 2013 lebih besar daripada tahun 2014. Sebagai contoh lainnya pada bank BRI Syariah, pada tahun 2014 memiliki aktifitas bagi hasil yang lebih tinggi daripada tahun 2013.

\section{Kesimpulan}

Kecukupan modal, Efektifitas Dana Pihak Ketiga, Resiko Pembiayaan, Penghapusan Aktiva Produktif, BOPO dan BI rate tidak berpengaruh signifikan terhadap Profit Distribution Management, sehingga dari hasil ini memberikan informasi bahwa keenam variabel tersebut tidak memiliki dampak tajam dalam mempengaruhi Profit Distribution Management, sehingga deposan perlu mempertimbangkan faktor diluar keenam variabel tersebut.

\section{Ucapan Terimakasih}

Peneliti mengucapkan terima kasih kepada pihak-pihak yang telah membantu selesainya penelitian ini dan kepada pihak pengelola Jurnal Ilmiah Ekonomi Islam STIE AAS Surakarta yang telah berkenan menerbitkan artikel kami.

\section{Daftar Pustaka}

Andreany, D. (2011). Analisis Pengaruh Dana Pihak Ketiga, Tingkat Bagi Hasil, Dan Non Performing Financing Terhadap Volume Pembiayaan Berbasis Bagi Hasil Pada Perbankan Syariah Di Indonesia. Simposium Nasional Akutansi XIV Aceh , 1-28.

Anshori, A. G. (2006). Gadai Syariah di Indonesia Konsep, Implementasi. Yogyakarta: Gadjah Mada University Press. Anshori, A. G. (2006). Hukum dan Pemberdayaan Zakat: Upaya Sinergis Wajib Pajak di Indonesia. Yogyakarta: Philar Media.

Anshori, A. G. (2009). Perbankan Syariah Indonesia. Yogyakarta: Gadjah Mada University Press.
Antonio, M. S. (2001). Bank Syariah, Dari Teori Ke Praktek. Jakarta: Gema Insani Press.

Farook, S., Hassan, M. K., \& Clinch, G. (2009). Profit Distribution Management by Islamic banks: An Empirical Investigation. The Quarterly Review of Economics and Finance .

Freeman, R. (1984). Strategic Management. A Stakeholder Approach. Boston: Pitman Publishing.

Ghozali, I. (2016). Aplokasi Analisis Multivariate Dengan Program IBM SPSS 21, Edisi 8. Semarang: Badan Penerbit Universitas Dponegoro.

Ghozali, I., \& Chariri, A. (2007). Teori Akuntansi Edisi 3. Semarang: Badan Penerbit Universitas Diponegoro.

Gujarti, Porter, D., \& Dawn. (2009). Basic Economitics Fifth Edition. Singapore: MC Grawl Hill.

Hadi, C. (2011). Problematika Pembiayaan Mudharabah Di Perbankan Syariah di Indonesia. Jurnal Maslhah, Vol2 No1.

Haque, Z. (1995). Riba: The Moral Economy of Usury, Interest and Profit. Kuala Lumpur: S. Abdul Majeed and Co.

Hasbi, \& Haruman. (2011). Metode Bisnis Untuk Akuntansi Manajemen, Edisi Pertama. Yogyakarta

Indriantoro, N., \& Supomo, B. (1999). Metode Penelitian Bisnis Untuk Akuntansi Manajemen, Edisi Pertama. Yogyakarta:

Kartika, S. B., \& Adityawarman. (2012). Analisis Faktor-Faktor Yang Mempengaruhi Profit Distribution Management, Studi Empriris Bank Umum Syariah di Indonesia Periode 2009-2012 Vol1 No1 . Diponegoro Journal Of Accounting.

Machmud, A., \& Rukmana. (2010). Bank Syariah, Teori, Kebijakan dan Studi Empiris di Indonesia. Jakarta: Erlangga.

Masruroh, F. W. (2016). Analisis Profit Distribution Management (PDM) Bank Syariah di Indonesia Periode 2010-2014. 
Jurnal Ilmiah Ekonomi Islam, 5(03), 2019, 264

Muhammad. (2005). Manajemen Pembiayaan Bank Syariah. Yogyakarta: UPP AMP YKPN.

Muhammad, (2006). Teknik Perhitungan Bagi Hasil dan Profit Margin Pada Bank Syariah. Yogyakarta: UII Press.

Mulyo, G.P., \& Mutmainah, S. (2013). Determinan Profit Distribution Management Bank Syariah di Indonesia Periode 20082011. Jurnal Ekonomi, Manajemen dan Akutansi Islam Vol1, No1 , 31-41.

Nurhayati, S., \& Wasilah, (2014). Akuntansi Syariah di Indonesia, Edisi 3. Jakarta: Salemba Empat.

Obaidullah, M. (2005). Islamic Financial Services. Jeddah: Islamic Economics Research Center King Abdul University.
Sugiyono. (2008). Metode Penelitian Bisnis. Bandung : Alfabeta.

Wafaretta, V., \& al, e. (2015). The Impact Of Banks Charateritics on Profit Distribution Management of Islamic Banks, Vol 219. Procedia - Social and Behavior Sciencs, 769-776.

Wibowo, E.S., \& Syaichu, M. (2013). Analisis Pengaruh Suku Bunga, Inflasi, CAR, BOPO, NPF Terhadap Profibilitas Bank Syariah Vol2 No2. Diponegoro Journal of Management , -.

Yani, Sri, \& Layla. (2006). Persaingan Perbankan di Indonesia.-: Buletin Ekonomi.

Yaya, Rizal, \& etal. (2009). Akuntansi Perbankan Syariah, Teori dan Praktik Kontemporer. Jakarta: Salemba Empat 